\title{
HANNAH AND HER PRAYERS
}

Adele Berlin

University of Maryland

\begin{abstract}
This essay, dedicated to my friend and colleague, Yehoshua Gitay, discusses the story of Hannah, with emphasis on the speeches and on Hannah's two prayers, the prose prayer embedded in the narrative and the poetic prayer that follows it. The two prayers are compared in terms of their rhetoric and their function.
\end{abstract}

Hannah is a barren mother. That is, her story, like those of Sarah, Rebecca, Rachel, and Samson's mother, employs the motif of a woman who is barren for a long while and then gives birth to a child of special destiny. As in the case of Sarah and Rachel, another woman is involved, a co-wife named Peninah, who is fertile while Hannah is not, and who feels superior to Hannah for that reason. Peninah is a wife of equal status to Hannah, not a slave woman like Hagar but a full-status wife like Leah. Since Hannah is listed before Peninah, we may assume that she was Elkanah's first wife. In any case, as we soon see, she is clearly his favorite.

The first thing we are told about the women is that Peninah had children and Hannah did not. The juxtaposition of Peninah's children with Hannah's lack of children immediately alerts the reader to trouble ahead; there is inequality between two equals. Hannah is inferior, a failed wife, in her own eyes and in the eyes of society.

The second thing we learn, also background for the main plot, is about the dynamics of this family, as they play out year after year during the pilgrimage to Shiloh, the local sanctuary where sacrifices were conducted. Note that what transpires is in public view; the family is not at home but at the local religious center. The sacrifice was accompanied by a festive ritual meal at which some of the sacrificial meat was eaten. At these meals, Elkanah would give Hannah a special portion, most likely a double portion, ${ }^{1}$ because, as the text says, כי את חנה אהב וה' סגר רחמה, "for it was Hannah he favored and/but God had closed her womb." Did Elkanah favor Hannah because she was barren, or in spite of it? The copula is ambiguous and the translations are not in agreement. NJPS, for example, renders: "for the Lord had closed her womb," while NRSV reads: "though the Lord had closed her womb." That Elkanah favored Hannah in spite of her barrenness is the more natural reading, and many commentators accept it. But in light of what follows in the story, it may be that NJPS has captured a more subtle nuance - that Elkanah showed favor to Hannah by giving her a special portion because she was barren. Elkanah, here and in v. 8, is trying to compensate for Hannah's barrenness. We may infer that Elkanah would not have given Hannah a special portion if she had had children, even if she were the favorite wife.

Peninah was quite naturally jealous of Hannah's special treatment, and taunted Hannah about her childlessness (the reason for the special treatment). It seems possible that Peninah would not have taunted Hannah had Elkanah not given her a special portion. At least that can be inferred from the way vv. 5-6 are structured.

1. On מנה אחת אפים see Simon, Reading Prophetic Narratives, 273 n. 15. 
Hannah must have been miserable enough already, but Peninah's taunts made her feel worse. She would cry and refuse to eat. Not eating is a common sign of depression in the Bible, and here the effect is even more pronounced, because Hannah's refusal to eat means that she is not participating with the rest of the family, and not eating the special portion that Elkanah gave her. Hannah does not utter a word, but Elkanah says: "Why are you crying, why do you not eat, Why do you feel so bad? Am I not better for you than ten sons?" The same phrase occurs in Ruth 4:15, when, after Ruth has a child, the women speak of her to Naomi as: "Your daughter-in-law who is better for you than seven sons." In both cases, the expression means that having X compensates for not having children. ${ }^{2}$ Ruth surely compensated for Naomi's lack of sons by producing a child to continue Naomi's family line. In what sense does Elkanah compensate for Hannah's infertility? By his kind words and special treatment, intended to blunt the shame and longing felt by Hannah because of her infertility. Elkanah feels personally responsible to make up for Hannah's lack of children. Several modern commentators think that this makes Elkanah look less than heroic. They think he does not realize that gifts and compliments cannot take away Hannah's deep longing for a child. ${ }^{3}$ My own estimation of Elkanah is more sympathetic. I see him as an unusually sensitive husband. No other husband of a barren woman in the Bible reacts this way. On the other hand, Elkanah seems to have given up hope that Hannah will bear a child, or to not care (perhaps because he already had children); he does not entreat God on her behalf, as Isaac does in Gen 25:21. Hannah, though, does not give up hope; she goes on her own, without her husband's knowledge, to ask God for a son. However one views Elkanah, he is, after all, a minor character in the story. His literary function is to dramatize Hannah's feelings and make them all the more poignant. His words "Am I not better for you" focus the spotlight on Hannah, emphasizing that she is the central character in the narrative.

Hannah is not consoled by her husband's kind words and deeds, for nothing he can do or say will compensate for her lack. She will not feel better, as signaled by her eating, until after she has prayed to God to grant her a child. ${ }^{4}$ As it says after her encounter with Eli at the sanctuary at Shiloh, "The woman left, and she ate, and she was no longer downcast." Notice that she feels better immediately after she has prayed but before the prayer has been granted. Hannah is a woman of rare faith.

All throughout these yearly tableaus, which set the scene for the main action, Hannah is silent. She does not utter a word until the main plot begins. Moreover, her words are not addressed to the members of her family, but to God and then to Eli, the priest at Shiloh. The main action centers on Hannah's prayer.

2. I do not think that the translation "better to you" rather than "better for you," as some translations render it, is correct. The point is not that Elkanah treats Hannah even better than would be warranted if she had many children (so McCarter, 60). Nor does NJPS “Am I not more devoted to you than ten sons?" have much to recommend it. The issue is not the devotion of sons vs. the devotion of Elkanah. Hannah is not feeling a lack of devotion.

The insight of Zvi Adar, quoted by Simon, 14, that a more expected response by Elkanah would be "are you not better for me than ten sons," also now seems to me to be deficient (although I was once taken by it). That Elkanah would say that having Hannah is better than having ten sons would move the focus from Hannah's lack to Elkanah's lack. But the lack is Hannah's, not Elkanah's; Elkanah already has children. To say to Hannah that Elkanah loves her more because she is barren, while perhaps true (see v. 5), seems hardly comforting.

3. Alter, The David Story, 4; Simon, Reading Prophetic Narratives, 14, 18, 24.

4. With several commentators, I take v. 9 to mean that Hannah arose "after the eating" - that is, after the other members of the family had eaten, not after she herself had eaten, for she did not eat until later. 
We now come to the events of one particular pilgrimage to Shiloh. As before on similar occasions, Hannah is distressed by her inability to have a child. After the family's eating and drinking, in which she presumably did not participate, ${ }^{5}$ Hannah rose and went into the room in the sanctuary where the ark of God was kept, called the temple of the Lord. The MT does not make her location clear, but the LXX says: "She rose and stood before the Lord." Eli was stationed at the doorpost (or entrance) of the temple of the Lord, where he could see and hear Hannah although she could not see him. This description of the scene makes most sense if she was inside the temple of the Lord. This is the same place where, later, the young Samuel will have his first call from God. In this place, God's presence is most keenly felt; it is the place where communication between God and humans is most likely to occur.

Hannah, thinking she is alone, prays to God. But Eli, standing out of Hannah's sight, sees and hears her, although he does not comprehend what he is seeing and hearing. His misunderstanding is a classic, and adds tension to the scene. Moreover, the two intertwined stories of the rise of Samuel and the decline of Eli's line come together at this moment, as Eli witnesses Hannah's prayer to conceive the very child who will bring his priestly line to an end. Ironically, he endorses her prayer with a blessing, the irony coming from the fact that Eli did not know what Hannah was praying for.

There are really two prayers of Hannah. The first is a prose prayer, uttered by the barren woman in the sanctuary at Shiloh. It is a plea for a child, with the promise that if God will grant the request, the child will be dedicated to God's service.

Now she was bitter of soul and she prayed to the Lord and cried intensely. And she made a vow and said: "Lord of Hosts, if you will really see your servant's suffering, and take notice of me and don't ignore your servant, and give your servant a male child, I will give him to the Lord all the days of his life and no razor shall go up upon his head" (1:1011).

There are two types of prayer in the Bible. Formal public prayers are always in poetry, as in Psalms or laments. Prose prayer are the prayers of individuals, not the community, and they do not have fixed wording. Moshe Greenberg, who has studied prose prayer in the Bible, notes that unlike poetic prayers or psalms, prose prayers arise out of a particular, momentary need. They thus convey an immediacy and a personal-ness that is lacking in the more formal and formulaic poetic prayers. Nevertheless, although they are spontaneous, prose prayers follow a regular pattern, consisting of an address invoking God, a petition (which is the heart of the prayer), and the motivation - the reason that God should grant the petition. Hannah's prayer follows this pattern clearly. She addresses God, asks for a child, and provides the motivation by promising to dedicate the child to God's service.

The stipulation that no razor shall go upon his head means that the child will be a Nazirite, a person who takes upon himself the extra religious obligations not to drink wine and not to cut his hair. That a mother would make a Nazirite vow for an unborn son is highly unusual. ${ }^{6}$ In Samson's case, the angel who announces his birth also announces that he is to be a Nazirite, and that he is to abstain from wine even in utero (Jud 13:4). The same prenatal abstinence apparently holds true for Samuel. For, while the others at Shiloh ate and drank (the common drink being wine), no mention is made of Hannah's drinking. The absence of drink is notable; when Hannah takes her leave, the text (v. 18) says only that she

5. See previous note.

6. Fishbane, Haftarot, 373. 
ate, not that she drank. ${ }^{7}$ Ironically, Eli accuses Hannah of being drunk, a charge that she denies and that the reader knows to be false. ${ }^{8}$ This underlines the Nazirite vow, although refraining from wine is not articulated in the vow itself.

Let us look more closely at Hannah's prose prayer, and at the narrative context surrounding it. The narrative stresses the idea of praying: it uses this term before the actual words of the prayer, and again immediately afterwards. First the narrator tells us: "Bitter of soul, she prayed to the Lord, crying all the while." At the end of the prayer, we are told: "And it was that she prayed a long while before the Lord." At this point we realize that even we readers have not heard Hannah's full prayer, but only enough to know what she prayed for. This is no quick request, but a prolonged plea to God, perhaps repeated many times.

It was during all this time that Eli was watching her, but since Hannah's prayer was soundless, he did not realize that she was praying. Misunderstanding what he saw - moving lips with no words emerging - he took her for a drunken woman and warned her to sober up. His misunderstanding makes perfect sense, for ancient prayer was not silent. The words were articulated aloud, so that God would hear them. "Hear my prayer, Lord," is a common liturgical formula.

Hannah then explains her actions to Eli in the following words:

No, Sir, I am a very unhappy woman. Wine or strong drink I have not drunk, but I have been pouring out my heart to the Lord. Don't take your servant for a worthless woman, for out of my great anguish and distress have I spoken all this time.

Notice that Hannah does not mention the word "pray," and makes no reference to the words that she uttered. Rather, she justifies herself as a distraught and emotional woman who was "pouring out her heart before the Lord" in what still must have seemed to Eli to be an incoherent attempt to entreat God, from a surfeit of emotion if not from wine. Eli, regretting his false accusation, sends her on her way with a generic blessing: "May the God of Israel grant your request that you requested from him." Eli has come to understand, somewhat belatedly, that Hannah had communed with God, but he has no inkling what she requested. Hannah tells him only much later, when the child has been born and she comes again to Shiloh to fulfill her promise to dedicate him to divine service. At that time she says to Eli:

Please, Sir, by your life, Sir, I am the woman who stood with you here to pray to the Lord.

For this boy did I pray, and the Lord granted me my request that I requested from him.

Her words are carefully arranged. This time she uses the term "pray" and reveals the contents of her prayer (which the reader knew all along but Eli did not). And she cleverly incorporates Eli's earlier words, too, - "May God grant your request that you requested of him" - thus tying up his perspective with ours and verifying that his blessing was efficacious.

Why does Hannah initially withhold her act of praying and her prayer from Eli? Would it not have garnered more sympathy from him if he had known more about what transpired? Would it not have evoked his priestly powers of intercession even more strongly and purposefully on her behalf?

We learn a lot about the characters of Eli and Hannah from these exchanges of words. This is the first time, but not the last, that Eli is slow to realize that someone close to him is in communication with God. Here, as soon afterwards with the young Samuel, it slowly

7. For a discussion of the LXX's addition, including that Hannah drank, see Simon, Reading Prophetic Narratives, 276 n. 34

8. Alter, The David Story, 5, notes the irony. 
dawns on him that the line of communication between God and another person is opening, but here, as there, he is not privy to what is being said. Poor Eli is increasingly left out of the action. He and his line are being replaced by Samuel, and this is foreshadowed even before Samuel is born. Indeed, it is foreshadowed with irony, for when Eli wishes Hannah success in her petition, he is unwittingly endorsing the request for the birth of the person who will supplant his own sons.

And what do we learn about Hannah? She, of course, serves the greater needs of the narrative, whose main burden is to recount the rise of Samuel, who will replace Eli and inaugurate kingship in Israel. But we also learn an important lesson from Hannah about the efficacy of prayer and, more specifically, about when to reveal one's prayer to others. What if she had told Eli her prayer and God had not seen fit to grant it? Then both she and God might look bad. Either she would look unworthy or God would look powerless. One should not reveal one's petition to God before it has been granted, lest, if it is not granted, God's reputation be diminished. The time to reveal the petition is after it has been granted, for then the grace and power of God can be seen by all.

That is just what Hannah does, and her gratitude to God is made manifest in her second prayer - the poetic and public prayer in which she gives thanksgiving. This prayer is psalmlike; and, in fact, several of its verses echo verses in the book of Psalms. It employs so much stereotyped imagery that some commentators have suggested that it existed as a separate poem and was inserted here by the author of the book of Samuel. We cannot know for sure, but in any case it is not unusual for a person who wants to offer a formal prayer to use a pre-existing one. That is why liturgies are created. We cannot all be poets, and there is something very comforting and satisfying in calling upon a well-established prayer to express our own needs. So I don't find it a failing if Hannah or the author of her story used a ready-made thanksgiving prayer. Prayers like this are meant to be re-used. Here we see clearly the difference between biblical prose prayer, a one-time, spontaneous, and individual outpouring, and poetic prayer, a more enduring, re-usable, and artistic type of composition.

Hannah's poetic prayer teaches us something else. When we look at its movement we see that it begins with the first person, "I": "My heart exults ... my horn is raised ... my mouth is wide ... for I rejoice." Hannah is very full of herself and her own emotion at being granted her petition. But quickly the prayer moves to focus on the source of Hannah's joy: God. And, indeed, most of the prayer is about God and his acts, described in a global way. There is no one like God. He weakens the mighty and strengthens the weak. He enriches the poor and impoverishes the rich. God can bring about any type of reversal, just as he did in Hannah's case. Hannah's thanksgiving blends into praise of God; she uses her own happy occasion to praise God, to show her audience the power of God. In the course of doing so, a personal moment becomes an emblem for the nation - and herein lies the power of the prayer. This is clearest in a phrase that frames the poem, occurring near the beginning and the end. The phrase is ramah qeren, literally "to raise the horn," an idiom for triumph. "My horn is raised through the Lord," declares Hannah in the first verse, meaning that the Lord has given her a victory. And in the last verse she says:

"He will give strength to his king, and will raise the horn of his anointed one."

As we found in our analysis of the prose prayer a premonition of the rise of Samuel, so we find here even more strongly a hint of the future kingship, specifically the Davidic kingship. This verse has its counterpart near the end of the Book of Samuel, in David's poem, that ends with the well-known verse: 
"Tower of victories/ He magnifies the victories of his king and shows loyalty to his anointed one, to David and to his seed forever."9

This is the essence of what the Book of Samuel is about. Its subject is the establishment of the Davidic dynasty, and from the outset it is leading up to David's reign. Into Hannah's mouth are put words of prophecy about the future king. Hannah's prayer may have been written separately from the book of Samuel, but it fits the needs of its present context exactly. Those needs are both personal and national. The child that Hannah prayed for will become the prophet who anoints King David. The beauty of this poetic prayer is that it shows us the link between the personal and the communal. Unlike biblical prose prayer, biblical poetic prayer is communal. When an individual recites a communal prayer, the personal merges with the communal. Prose prayer may be more spontaneous, more specifically tailored to the occasion, but poetic prayer puts the individual's thoughts in the context of the community, so that the individual stands before God as part of a larger entity, with a concomitantly stronger claim to call upon God. Communal prayer transcends the personal situation in which it is recited.

\section{BIBLIOGRAPHY}

Alter, Robert 1981. The Art of Biblical Narrative. New York: Basic Books.

Alter, Robert 1999. The David Story. New York and London: WW Norton.

Fishbane, Michael 2002. Haftarot. The JPS Bible Commentary. Philadelphia: Jewish Publication Society. Pp. 369-377.

Greenberg, Moshe 1983. Biblical Prose Prayer as a Window to the Popular Religion of Ancient Israel. Berkeley: University of California Press.

Janzen, J Gerald 2003. "Prayer and/as Self-Address: The Case of Hannah" in A God so Near. Essays on Old Testament Theology in Honor of Patrick D Miller. Edited by Strawn, Brent A and Bowen, Nancy R. Winona Lake, In: Eisenbrauns. Pp. 113-127.

McCarter, P Kyle 1980. I Samuel. A New Translation with Introduction and Commentary (AB 8). Garden City: Doubleday.

Polzin, Robert 1989. Samuel and the Deuteronomist. San Francisco: Harper and Row.

Simon, Uriel 1997. Reading Prophetic Narratives. Bloomington: Indiana University Press.

Zalevsky, Saul 1987. "The Vow of Hanna (1 Samuel 1).” Beth Mikra 23: 304-326.

9. On the link between these two poems see Simon, Reading Prophetic Narratives, 278 n. 53 and 279 n. 54 ; and Polzin, Samuel and the Deuteronomist, 32-34. 